UIdaho Law Digital Commons@ UIdaho Law

Faculty Scholarship

2015

\title{
A Coordinated Approach to Food Safety and Land Use Law at the Urban Fringe
}

Stephen R. Miller

University of Idaho College of Law, millers@uidaho.edu

Follow this and additional works at: https://digitalcommons.law.uidaho.edu/faculty_scholarship

Part of the Food and Drug Law Commons, and the Land Use Law Commons

\section{Recommended Citation}

41 Am. J. L. \& Med. 422 (2015).

This Article is brought to you for free and open access by Digital Commons @ UIdaho Law. It has been accepted for inclusion in Faculty Scholarship by an authorized administrator of Digital Commons @ UIdaho Law. 
American Journal of Law \& Medicine, 41 (2015): 422-446 American Society of Law \& Medical Ethics, (C) 2015 The Author(s)

Boston University School of Law

DOI: $10.1177 / 0098858815591526$

\title{
A Coordinated Approach to Food Safety and Land Use Law at the Urban Fringe
}

\author{
Stephen R. Miller
}

Much has been written about the rise of the local food movement in urban and suburban areas. This essay tackles an emerging outgrowth of that movement: the growing desire of urban and suburban dwellers to engage rural areas where food is produced not only to obtain food but also as a means of tourism and cultural activity. This represents a potentially much-needed means of economic development for rural areas and small farmers who are increasingly dependent on non-farm income for survival. The problem, however, is that food safety and land use laws struggle to keep up with these changes, waffling between overregulation and de-regulation. This essay posits a legal path forward to steer clear of regulatory extremes and to help the local food movement grow and prosper at the urban fringe. We must cultivate our garden. ${ }^{1}$

- Candide, or Optimism

\section{INTRODUCTION}

Over the past several decades, a resurgent interest in food has brought agricultural production into American cities. Just as in Voltaire's classic work, Candide, where the namesake character travels the world over only to decide it is best to be at home "cultivat[ing] our garden," so, too, have many urban and suburban dwellers found great interest in locally grown food. Manifestations of this boom include the rise of farmer's markets and community gardens, as well as the proliferation of urban agriculture ordinances. Such ordinances typically include provisions allowing urbanites to keep chickens, grow gardens in their front yards, and engage in micro-

${ }^{\dagger}$ Associate Professor of Law, Director, Economic Development Clinic at the University of Idaho College of Law. A.B., Brown University; M.C.P., University of California, Berkeley; J.D., University of California, Hastings. The author wishes to acknowledge the helpful comments of Profs. Anastasia Telesetsky and Sarah Shindler, as well as the contributions of students in his 2013-14 Economic Development Clinic-Tyler Beck, Caitlin Fuller, and Alexandra Grande-at the University of Idaho College of Law. Mr. Beck, Ms. Fuller, and Ms. Grande provided excellent research on legal tools to facilitate onfarm diversification activities, which forms the background for several parts of this article.

${ }^{1}$ VOlTAIRE, CANDIDE, OR OPTIMISM 119 (Peter Constantine trans., Random House 2005) (1759). 
scale agricultural production, ordinarily for personal use and, occasionally, for sale at farmer's markets and neighborhood use. ${ }^{2}$ What has received less attention is an emergent boomerang effect of this movement: while the first wave of urban agriculture has brought agriculture to the cities, city dwellers increasingly want to go to rural areas to visit agriculture in its native habitat. Wine drinkers want to visit the vineyards of their favorite wine; raw milk purchasers want to visit the farmer and the cows that made their milk; organic produce lovers want to have farm-to-table dinners in barns just feet from where the food was grown; meat lovers want to purchase beef directly from the rancher who raised-and slaughtered-the animal. Different names have been given to the movement, such as agritourism ${ }^{3}$ or, sticking with the contemporary movement's Italian antecedents, agriturismo." Those who take to the movement had been called the "new agrarians" and "urbanistas." But none of these names capture the essence of the exploding, but nascent, movement at the rural urban fringe. Indeed, the very rise of the movement is as if today's modern Candides had decided not simply that the best of all possible worlds was in the tending of gardens, but in the tending of foodsheds. As such, the regulatory structures that need revisiting are not just those of urban and suburban areas, but the rural areas to which the local food movement now turns.

In discussing the movement, this article will use the term "food agritourism" to mean those activities, not readily fitting into existing norms of agriculture or food production, that have the following five characteristics: a local grower or producer; growing and harvesting food; producing and selling a food product; marketing activities around food products that may, or may not, involve food; and a location that is rural in character, typically at the urban edge, and that may or may not have an agricultural use on premises.

While "food agritourism" is an admittedly imperfect term, simply having any name at all for the movement can help to begin a more coherent conversation about the regulatory structures that should apply to it. While the movement has brought a spate of new business, and promises even more business, to small farmers desperate for

\footnotetext{
${ }^{2}$ See, e.g., Madeline Fletcher et al., Overcoming Barriers to Cultivating Urban Agriculture, 41 REAL EST. L.J. 216, 220-22 (2012) (discussing Jersey City's urban gardens); Mia Shirley, Food Ordinances: Encouraging Eating Local, 37 WM. \& MARY ENVTL. L. \& POL'Y REV. 511, 511-13 (2013); Matthai Kuruvila, Oakland Allows Urban Farmers to Sell Produce, S.F. CHRon. (Oct. 5, 2011), http://www.sfgate.com/ homeandgarden/article/Oakland-allows-urban-farmers-to-sell-produce-2328189.php (describing Oakland code change permitting urban farmers to sell food grown on residential lots).

3 See, e.g., Agritourism, NAT'L AGRIC. L. CTR., http://nationalaglawcenter.org/ research-bytopic/agritourism-2/ (last visited Mar. 3, 2015).

${ }^{4}$ See Patrick Symmes \& Peter Frank Edwards, Slow Food and Agritourism in the Pacific Northwest, CONDÉ NAST TRAVELER (Feb. 12, 2013), http://www.cntraveler.com/stories/2013-02-12/best-slow-foodpacific-northwest-farm-to-table-restaurants.

${ }^{5}$ See Laurie A. Ristino, Back to the New: Millennials and the Sustainable Food Movement, 15 VT. J ENVTL. L. 1, 19 (2013) (describing characteristics of the "new agrarians" as: "[f]acility with technology; [m]arketing skills to develop new economic activities; [e]mbrac[ing] farms as a food business which can serve as a platform for other entrepreneurial endeavors; [c] apacity and leadership to generate local development; [v]alu[ing] sustainability and environmental conservation, not as a burden but as a responsibility; [clommitment to the idea of community; [r]elationship-oriented (to the consumer, neighboring farmers, and the land); [and] [b]eliev[ing] farming and producing food is a social good.").

${ }^{6}$ See Alec Wilkinson, Read It and Reap: "Modern Farmer" and the Back-to-the-Land Movement, NEW YORKER (Nov. 10, 2014), http://www.newyorker.com/ magazine/2014/11/10/read-reap.
} 
secondary sources of income, the movement's lack of definition within cultural consciousness has also affected its growth. In the regulatory context that this article will address, that same lack of definition has also made it unclear how, and if, the food agritourism movement should be regulated under existing laws intended to protect food safety, provide safe buildings, and rationalize land use patterns.

This regulatory confusion has led to two opposing problems. First, regulators' approach to food agritourism has typically been to view this new gray area of activity as one to be regulated through existing regulations for agriculture and food production. This has sometimes led to regulation that, while appropriate in scale to the larger agricultural and food production industries, is onerous, or even irrelevant, to the small food agritourism use. Second, the regulated food agritourism community, feeling overregulated because it does not have regulations tailored specifically to it, has sought legislative assistance, typically in the form of deregulation, to avoid the onerous requirements. The instincts of both the regulator and the regulated are understandable; however, this article argues that both over-regulation and deregulation are fraught with unnecessary pitfalls. In place of these extremes, this article proposes a coordinated regulatory approach to food agritourism that prioritizes both public safety and economic development of rural communities through food agritourism.

The article proceeds in Section II by first looking at the role of food agritourism in providing an alternative source of much-needed income diversification for small farmers. In Section III, the article reviews efforts to deregulate food agritourism from food safety requirements at the federal, state, and local levels. Section IV similarly reviews efforts to deregulate food agritourism from building and zoning codes at the state and local levels. Section $\mathrm{V}$ offers a proposed alternative to overregulation and deregulation, which implements aspects of both economic development and coordinated regulation. Section VI offers concluding remarks.

\section{FOOD AGRITOURISM AND THE RURAL ECONOMY ${ }^{7}$}

The rise of food agritourism and its import for rural farms at the urban edge must be understood against the backdrop of radical change in rural economies, as well as the rise in interest in food production generally. "In 1900, about 41 percent of the total U.S. workforce farmed. . . . [T]his share dropped to 16 percent in 1945, 4 percent in 1970 , and only 2 percent in $2000 . " 8$ This is due largely to dramatic increases in farm productivity in the late twentieth century and especially since $1980 .^{\circ}$ According to the President's Council of Economic Advisors, "farm productivity nearly tripled in the second half of the twentieth century, while nonfarm productivity increased by about 75 percent"; further, the Council noted that "[a]lmost all of this divergence in productivity growth occurred after 1980.". ${ }^{10}$ These economic factors are shifting many types of U.S. agricultural production away from smaller family-owned farms to larger

\footnotetext{
${ }^{7}$ This section draws, in part, upon Stephen R. Miller, Three Legal Approaches to Rural Economic Development, 23 KAN. J.L. \& PUB. POL'Y 345 (2014).

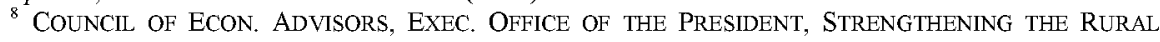
ECONOMY: THE CURRENT STATE OF RURAL AMERICA 5 (2010) http.//www.usda.gov/documents/Rural_America_final.pdf.

${ }^{9} I d$.

${ }^{10} \mathrm{Id}$.
} 
industrialized farming operations. ${ }^{11}$ Indeed, today's rural economies are exceedingly diverse in both economic activity and employment. ${ }^{12}$

Despite record United States agricultural exports and net farm income in recent years ${ }^{13}$ small farms are largely not sustainable solely as agricultural uses. ${ }^{14}$ For those remaining on small family farms, off-farm income has provided the lion's share of income-upwards of $90 \%$ of household income-for at least a decade. ${ }^{15}$ Most of small farmers' off-farm income is from wage-and-salary jobs or self-employment either in the adjoining rural economy or, more likely, a nearby city. ${ }^{16}$

This has special importance for small farms, for, as profits from traditional farming have been declining, smaller farm operators have increasingly turned to alternative sources of income as a way to supplement their household earnings and maintain their way of life. ${ }^{17}$ An alternative to off-farm income is referred to by the United States Department of Agriculture's Census of Agriculture as an "on-farm diversification activity." While this term includes a variety of activities, it generally encompasses activities meant to widen the base of a farm operator's business to include non-agricultural uses. As one report put it, an "on-farm diversification activity" is the "entrepreneurial use of a farm or agricultural resource for a nonagricultural purpose for commercial gain." 18

At the same time, an increasing attention to food among urban populations has also manifested itself in an increasing desire to more fully experience food production. ${ }^{19}$ In urban areas, this has been evidenced in the rapid rise of farmers' markets, ${ }^{20}$ as well as ordinances amending codes to permit chickens and front-yard

\footnotetext{
${ }^{11}$ See Robert A. Hoppe ET AL., USDA, SMALl FARMS IN THE UNITED STATES: PERSISTENCE UNDER PRESSURE 6 (2010). The United States Department of Agriculture (USDA) defines a farm as being "any place from which $\$ 1,000$ or more of agricultural products were produced and sold, or normally would have been sold, during the year." Farm Household Well-Being, USDA ECON. RES. SERV., http://www.ers.usda.gov/topics/farm-economy/farm-household-well-being/glossary.aspx (last updated Nov. $25,2014)$.

${ }^{12}$ See County Typology Codes: Descriptions and Maps, USDA, http://www.ers.usda.gov/dataproducts/county-typology-codes/descriptions-and-maps.aspx\#manufacturing (finding 585 nonmetropolitan counties' economies are manufacturing-dependent, 403 are farming-dependent, 222 are governmentdependent, 114 are services-dependent, 113 are mining-dependent, and 615 are non-specialized nonmetropolitan counties) (last updated Jan. 29, 2015).

$\begin{array}{lllllll} & \text { See USDA, USDA Agricultural Projections } & \text { to } & 2023 & 85 & \text { (2014), }\end{array}$ http://www.ers.usda.gov/media/1279470/oce141.pdf.

${ }^{14}$ See ROBERT A. HOPPE \& DAVID E. BANKER, USDA, STRUCTURE AND FINANCES OF U.S. FARMS: FAMILY FARM REPORT iv, 46 (2010), http://www.ers.usda.gov/media/184479/eib66_1_.pdf.

15 See U.S. Census Bureau, STATISTICAL ABstract of THE United STATES 538 tbl.830 (2012), http://www.census.gov/prod/201lpubs/12statab/agricult.pdf (indicating that family farms had an average off-farm income of $\$ 70,302$ and average on-farm income of $\$ 6,866$ in 2009).

${ }^{16}$ HOPPE \& BANKER, supra note 14 , at $\mathrm{v}$.

${ }^{17}$ See COUNCIL OF ECON. AdVISORS, supra note 8, at 4; NAT'L RURAL NETWORK, NRN CASE STUdY: FARM DIVERSIFICATION 2 (2012), http://www.nrn.ie/wp-content/uploads/2010/06/Final-Case-Study-onFarm-Diversification-May-2012.pdf.

${ }^{18}$ NAT'L RURAL NETWORK, supra note 17.

${ }^{19}$ See, e.g., Justin Rocket Silverman, New Yorkers Get a Taste of Rural Life at Clawhammer Farm in Lisle, N.Y., N.Y. DAILY NEWS (July 16, 2013, 2:00 AM), http://www.nydailynews.com/life-style/hipsterstaste-rural-life-clawhammer-farm-article-1.1399354\#ixzz30y V22xuG.

20 See USDA, FARMERS MARKET SERVICES, http:/www.ams.usda.gov/AMSv1.0/ getfile?dDocName $=$ STELPRDC5080175\&acct=frmrdirmkt (indicating at least $\$ 1$ billion in annual sales at farmers' markets nationally).
} 
gardens in areas where they were previously zoned out. ${ }^{21}$ At the same time, there has been a desire of urbanites to experience rural life and interact, in some meaningful fashion, with agricultural production. According to the 2007 National Survey on Recreation and the Environment, respondents listed the following reasons for why they visited a farm, ranch, or rural setting: enjoy rural scenery (rated important by $75 \%$ ); visit family and friends (53\%); learn about where food comes from (46\%); watch and participate in farm activities (43\%); purchase agricultural products/pick produce $(34 / 32 \%)$; spend the night (33\%); and hunt and fish (14\%). ${ }^{22}$ Participating in the place where food or agriculture products are made-whether it is through a farm-to-fork dinner or a wine-tasting event-is rapidly gaining ground as a means of leisure-time activity. ${ }^{23}$

Most of these rural, agriculture-centered diversification efforts are based upon selling food, or they otherwise sell food as a part of another non-food activity. This has led to an intersection of food safety law and land use law in rural communities that, previously, had little precedent. As this movement expands, there is a growing need to understand how regulations for food safety and land use can work together in regulating this increasingly common rural use. The problem, however, is that there is little formal discussion of the change that is coming about, and thus little effort to provide a holistic solution to the problems. Instead, farmers upset with the regulatory problems they face have sought the exact opposite - deregulation - on the food safety and land use fronts. However, this article posits that the dramatic efforts to effectively eliminate food safety and land use regulations governing food agritourism use may ultimately jeopardize the entirety of the movement. Potential hazards for the industry include an inability to shut down rogue businesses, potential perceptions of cronyism that will taint the industry once these exemptions become public, and potential perceptions of danger in the product equally resulting from the lack of regulation. There is no need for this nascent industry to place itself at such a risk of real, or even perceived, disadvantage in the marketplace. Instead, this article will argue for, and offer, several options for a more coherent regulatory approach to these food agritourism uses that would continue to regulate to protect public health and safety, permit and encourage growth of the agritourism uses, and also protect the industry.

\section{THE CASE OF FOOD SAFETY}

Food products sold in food agritourism vary widely, which is a major factor contributing to the confusion in regulating the industry. On the one hand, food agritourism could involve "U-picks" where customers pick their own apples, peaches, or strawberries. However, that same U-pick might also sell apple, peach, or

\footnotetext{
${ }^{21}$ See Patricia E. Salkin \& Amy Lavine, Regional Foodsheds: Are Our Local Zoning and Land Use Regulations Healthy?, 22 FORDHAM ENVTL. L. REV. 599, 620-23 (2011); Sarah Schindler, Of Backyard Chickens and Front Yard Gardens: The Conflict Between Local Governments and Locavores, 87 TuL. L. REV. 231, 240-42, 244-46 (2012). Ellie RILlA, ALl ABOUT AGRITOURISM 22 (2012), available at http://sfp. ucdavis.edu/files/143588.pdf (summarizing survey results of 2007 National Survey of Recreation and the Environment).

${ }^{23}$ See, e.g., Symmes \& Edwards, supra note 4 (discussing the growth and success of farm-to-table restaurants and agritourism at local farms and wineries in the Pacific Northwest).
} 
strawberry-rhubarb pies baked in a home kitchen. A nearby small dairy might sell raw, unpasteurized milk directly to consumers, and another farmer down the road might sell self-raised and slaughtered animals to nearby urban customers found through a local listing on a website like Craigslist. At the end of the road, an organic farm may run farm-to-table dinners on Saturday nights made from organic food planted adjacent to where the dinners are held. A collection of small farmers providing such opportunities for engagement with agriculture at the rural urban fringe is increasingly attractive to urban dwellers seeking to better connect with local food; moreover, such food agritourism is also an important secondary form of income to small farmers that need income diversification. Of course, those same urban dwellers expect that the food they purchase at food agritourism sites will be as safe, or safer, than what they can get in the local grocery store. What regulation, if any, is necessary to provide safety in these highly varied, direct-to-consumer transactions that will not kill the budding industry?

Unfortunately, food safety regulations that affect food agritourism operations have only referenced food agritourism obliquely. Instead, food agritourism has been wrapped up in larger efforts to regulate major agriculture and food production operators. In response, small food agritourism operators have engaged in successful efforts to deregulate food agritourism from many of these larger food safety requirements. There have been two components to this deregulation effort. First, there has been a sustained effort to eliminate regulation of food agritourism uses from recently enacted federal food safety regulation. Second, there has been an incremental local effort to eliminate food agritourism uses from state and local regulation as well. This section first reviews how local producers obtained an exemption from the most important federal food safety legislation since the Great Depression; then, the section evaluates how food agritourism is equally seeking exemptions from state and local laws.

\section{A. Federal Deregulation: The Tester Amendment to the FSMA}

In March 2009, President Barack Obama created the Food Safety Working Group (the "Working Group") to offer advice in three areas: first, "upgrad[ing] U.S. food safety laws for the 21st century"; second, "foster[ing] coordination of food safety efforts throughout the government"; and third, "ensur[ing] laws are being adequately enforced to keep the American people safe from foodborne illness."24 The impetus of the Working Group's creation was a series of high-profile foodborne illnesses arising from contamination in foods as disparate as ground beef, peppers, peanut butter, pistachios, spinach, and cookic dough. ${ }^{25}$

\footnotetext{
${ }^{24}$ FOOD SAFETY WORKING GROUP, FOOD SAFETY WORKING GROUP: KEY FINDINGS 2 (2009), http://www.foodsafetyworkinggroup.gov/FSWG_Key_Findings.pdf. "The Working Group [was] chaired by [then-] Health and Human Services Secretary Kathleen Sebelius and Secretary of Agriculture Tom Vilsack. Participating agencies include[d] the U.S. Food and Drug Administration (FDA), the Food Safety and Inspection Service (FSIS), the Centers for Disease Control and Prevention (CDC), the Department of Homeland Security, the Department of Commerce, the Department of State, the Environmental Protection Agency, and several offices of the White House." Id.

${ }^{25}$ See id. at 1; Nicholas Obolensky, The Food Safety Modernization Act of 2011: Too Little, Too Broad, Too Bad, 17 RoGER WILLIAMS U. L. REV. 887, 889 (2012) (discussing details of various foodborne illness cases in this time period).
} 
The Working Group identified a "perfect storm" of challenges to the food system, including new disease agents, an increasingly globalized food supply chain, changes in the U.S. population, and new dietary patterns. ${ }^{26}$ Among those challenges were intentional contamination, such as the introduction of melamine to food products in China, which killed six babies in China and threatened millions. ${ }^{27}$ Similarly, the globalization of the food market also presents new food safety issues. For instance, the Working Group noted that "the United States imports food from more than 150 different countries through more than 300 ports of entry; about half of fresh fruits eaten in America are grown outside of the country; and more than three-quarters of U.S. seafood comes from non-U.S. waters." 28 Further, the Working Group found that more Americans are eating prepared foods: "approximately 50 cents of every food dollar is now spent on food prepared outside the home in restaurants, vending machines, movie theaters, and schools." 29

In response to these challenges, the Working Group concluded that the nation's food safety system was "hamstrung by outdated laws, insufficient resources, suboptimal management structures, and poor coordination across agencies and states and local governments." 30 According to the Working Group, "at least a dozen [f]ederal agencies, implementing at least thirty different laws, [had] roles in overseeing the safety of the nation's food supply." not rationally designed" and needed to be fixed. ${ }^{32}$

In July 2009, the Working Group submitted a report in which it identified "three core food safety principles" to guide legislative action:

Principle 1: Preventing harm to consumers is our first priority; Principle

2: Effective food safety inspections and enforcement depend upon good data and analysis; [and] Principle 3: Outbreaks of foodborne illness should be identified quickly and stopped. ${ }^{33}$

The Working Group's analysis, principles, and recommendations became fundamental to debates on food safety legislation in Congress. On March 3, 2009, Senator Richard Durbin introduced a bill that, in time, would become the Food Safety Modernization Act of 2011 (FSMA). ${ }^{34}$ A full discussion of the FSMA is beyond the scope of this article; however, several overarching aspects of the legislation are worth noting. First, the FSMA provided the Food and Drug Administration (FDA) a legislative mandate to prevent harm from food as opposed to simply responding to outbreaks, a regulatory shift that represented a sea change in the agency's mandate. ${ }^{35}$ The FSMA requires "food facilities to evaluate the hazards in their operations, implement and monitor effective measures to prevent contamination, and have a plan

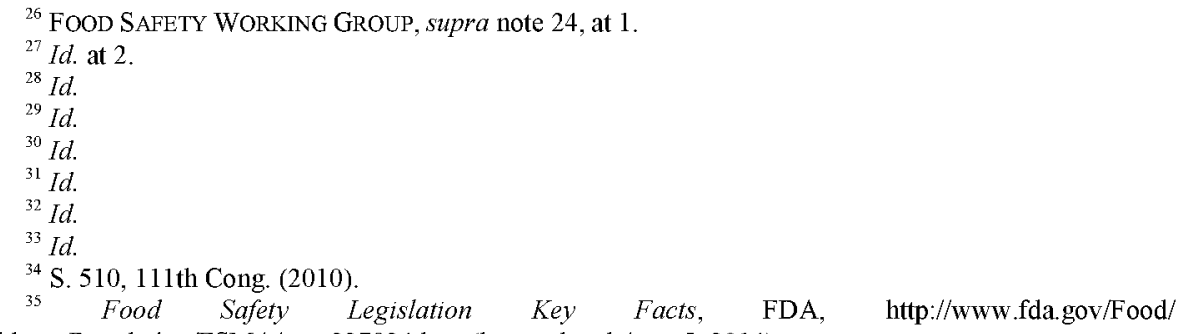
GuidanceRegulation/FSMA/ucm237934.htm_(last updated Aug. 5, 2014). 
in place to take any corrective actions that are necessary." ${ }^{36}$ The FSMA also required the FDA "to establish science-based standards for the safe production and harvesting of fruits and vegetables to minimize the risk of serious illnesses or death," and significantly enhanced the FDA's ability to oversee food products coming into the United States. ${ }^{37}$

As the FSMA legislation was being debated, however, a major controversy emerged on whether these new regulations for food safety should apply to all food production, or if there should be some exemption for local farmers and food producers and, if so, how such exemptions would be defined. Though thousands of comments were submitted to this point, two such comments are indicative of the relative positions. On the one hand were those such as food writer and locavore champion, Michael Pollan, who argued:

Today the revival of local food economies is being hobbled by a tangle of regulations originally designed to check abuses by the very largest food producers. Farmers should be able to smoke a ham and sell it to their neighbors without making a huge investment in federally approved facilities. Food-safety regulations must be made sensitive to scale and marketplace, so that a small producer selling direct off the farm or at a farmers' market is not regulated as onerously as a multinational food manufacturer. This is not because local food won't ever have food-safety problems - it will - only that its problems will be less catastrophic and easier to manage because local food is inherently more traceable and accountable. ${ }^{38}$

On the other hand was the testimony of Thomas E. Stenzel, the president and CEO of United Fresh Produce Association, before the Committee on Senate Health, Education, Labor and Pensions. Mr. Stenzel noted:

I also want to urge the committee to reject calls to "water down" the food safety requirements in the bill as a way to satisfy some who say that small farms, organic farms, or others should not have to comply. Mr. Chairman, I have a number of small farms and organic farms in our membership, and all are committed to following whatever food safety rules that FDA deems to be important to protect public health. Size does not determine whether food safety is important - every consumer's health is just as important whether purchasing vegetables at a farmers market or a grocery store. Our industry has learned the painful lesson that we are only as strong as our weakest link. If Congress truly wants to build public confidence in our food safety system, all fruits and vegetables must comply with basic safety rules no matter where or how grown.

Rather than seek exemptions from basic food safety requirements, we believe technical assistance, training and financial support-

\footnotetext{
${ }^{36} I d$.

${ }^{37} \mathrm{Id}$.

Michael Pollan, Farmer in Chief, N.Y. TIMES MAG. (Oct. 9, 2008), http://www.nytimes.com/2008/10/12/magazine/12policy-t.html?_r=1\&pagewanted=all.
} 
including reduced fees for all small businesses-are more appropriate ways to assist small resource farmers and produce distributors to comply with important food safety and traceability standards. We are confident that every produce grower-in this country or abroad-should be able to comply with the commodity-specific standards and guidance anticipated from FDA for the safe production and handling of fruits and vegetables. $^{39}$

In the final days of debate over the FSMA legislation, over objections of those such as Mr. Stenzel, Senator Jon Tester of Montana offered an amendment, which offered several exemptions from the legislation for small farmers and food producers. In general terms, the Tester Amendment exempted food producers from the new federal requirements if they "(i) sell the majority of their food directly to consumers within the state, or within a 275 -mile radius of where it was produced; and (ii) have less than $\$ 500,000$ per year in sales."40 The Tester Amendment passed and became an important part of the FSMA when it was signed into law by President Obama on January 4, 2011. ${ }^{41}$ Years after the FSMA became law, local food producers are still wrangling over the scope of the exemptions for local food producers as the FDA enters the final phases of its rulemaking process necessary to implement the law, a process that is slated to be finished in $2015 .^{42}$

In explaining his support of the exemptions for local food producers, Senator Tester stated in a press release on the amendment that the exempted food producers "would, however, continue to be overseen by local and state food safety and health agencies." 43 Tester clearly stated that the reason the exemption made sense was that state and local governments were better regulators of the local food movement. On the floor of the Senate, Senator Tester stated the following in extemporaneous remarks:

People have asked me . . . why do you think the small guys can even be regulated by the local and states regulators in this country? Well, first of all, they're small, there's a pride of ownership there that is real, they raise food, they don't raise a commodity as happens when the operations get bigger and bigger, and there is a direct customer relationship with that processor or that farmer that means a lot. And if a mistake is made, which rarely happens, it doesn't impact hundreds of thousands of people. We know exactly where the problem was, and we know exactly how to

${ }^{39}$ Food Safety: Hearing on S. 510 Before the S. Comm. on Health, Educ., Labor \& Pensions, 111 th Cong. (2009), (statement of Thomas E. Stenzel, President and CEO, United Fresh Produce Association).

${ }^{40}$ Press Release, Sen. Jon Tester, Senate Overwhelmingly Passes Food Safety Bill with Tester's Amendment (Nov. 30, 2010), available at $\mathrm{http} / / \mathrm{www}$. tester. senate.gov/? $\mathrm{p}=$ press release $\&$ id $=1078$.

${ }^{41}$ FDA Food Safety Modernization Act, Pub. L. No. 111-353, 124 Stat. 3885 (2011).

${ }^{42}$ See Current Good Manufacturing Practice and Hazard Analysis and Risk-Based Preventive Controls for Human Food, 79 Fed. Reg. 58,523 (proposed Sept. 29, 2014) (to be codified at 21 C.F.R. pts. 1, 16, 117); Standards for the Growing, Harvesting, Packing, and Holding of Produce for Human Consumption, 79 Fed Reg. 58,433 (proposed Sept. 29, 2014) (to be codified at 21 C.F.R. pt. 112); Maria Gaura, Food Safety Rules Proposed Today by FDA Show Promise for Organic Farmers, ORGANIC FARMING RES. Found. (Sept. 19, 2014, 3:50 PM)

http://www.ofrf.org/blogs/food-safety-rules-proposed-today-fda-show-promise-organic-farmers.

${ }^{43}$ Press Release, Sen. Jon Tester, supra note 40. 
fix it. . . [T]he connection with that consumer makes it so that local entities can do that regulation much better than us anyway. ${ }^{44}$

The passage of the FSMA with the Tester Amendment made clear that Congress did not imagine that it was eliminating all regulation of small farmers and food producers altogether. Rather, it appeared that Congress intended for legislation at the state and local level to continue on much as it had prior to the passage of the FSMA.

\section{B. State and local Deregulation: The Cottage Farm, Food Freedom, and FOOD SOVEREIGNTY MOVEMENTS}

The legislative battles around the FSMA had an unintended effect: while the battles led to increased regulation of major agricultural and food producer operations, they not only exempted small farmers and operators from federal regulation, but also galvanized such operators to seek similar exemptions from the very state and local government regulations that the FSMA exemption presumed would provide the bulwark of safety regulations for such operations. This section reviews how exemptions for small farmers and food producers have been sought at the state and local government levels through expansions in existing cottage food laws, as well as through a rising tide of anti-regulatory sentiment in the food sovereignty and food freedom movements.

\section{Cottage Food Laws}

The most common-and most longstanding-effort to reduce burdens on local food production is the cottage food laws. ${ }^{45}$ Despite the prevalence of such cottage food laws, historically, there has been scant legal attention paid to them. That changed with a 2013 study by the Harvard Food Law and Policy Clinic (Study). The Study provides much-needed insight into this movement, and several of its key findings are summarized here.

States have historically retained the power to write their own food laws; however, given the complexity of the subject matter and the relative lack of expertise at the state level, the Model Food Code, which is produced by United States Food and Drug Administration (FDA Food Code), ${ }^{46}$ has proven a popular basis for state food standards. Included in this FDA Food Code were food establishment provisions with which many cottage food producers found it difficult to comply. ${ }^{47}$

As a result, the Study found, two common methods of amending the FDA Food Code have emerged in recent decades at the state level to assist cottage food industry growth: (i) "modifying the definition of 'food establishment' to exclude home

${ }^{44}$ SenatorJonTester, Tester Food Safety Amendment Protects Family-Scale Producers, YouTuBE (Nov. 18, 2010), https://www youtube.com/watch? v=Awa0VmEmIoI (video of Senator Tester's speech on the Senate floor).

${ }^{45}$ See Alli Condra, Harvard Food Law \& Policy Clinic, Cottage Food laws in the United STATES 4 (2013), http://blogs.law.harvard.edu/ foodpolicyinitiative/files/2013/08/FINAL_Cottage-FoodLaws-Report_2013.pdf.

${ }^{46}$ HHS, FOOD CODE: 2013 ReCOMmendations of the United STATes Public Health SERvice (2013), available at http:/www.fda.gov/downloads/Food/ GuidanceRegulation/RetailFoodProtection/FoodCode/UCM374510.pdf.

${ }^{47}$ CONDRA, supra note 45 at 7 . 
kitchens"; and (ii) "creating a separate legal structure for cottage food production." Even with these statutory changes to the FDA Food Code, the Study found five types of restrictions on the cottage food industry remained: (i) limits on the "cottage food products allowed"; (ii) "limits on where cottage food products can be sold"; (iii) "required registration, licenses, and/or permits"; (iv) "limits on total sales"; and (v) labeling requirements. ${ }^{49}$

First, with regard to the types of cottage food products allowed, the Study found that states typically "limit cottage food production to foods that are "not potentially hazardous." $" 50$ Further, "[s]ome states provide a detailed list of allowed foods, while others simply require the food to be not potentially hazardous." ${ }^{51}$ Second, with regard to where food can be sold, the Study found that "[n]early all states restrict cottage food operations to selling directly to consumers and do not permit sales to restaurants or other retail food establishments." 52 The locations where cottage food sales can occur varies by state. ${ }^{53}$ Third, the Study found that states vary widely on the licensing and permitting of cottage food operations, as well as on the requirements associated with such authorizations. Some state statutes require licenses or permits; others are silent on the matter. ${ }^{54}$ Fourth, the Study found that "about half of the states that allow cottage food production place a limitation on the amount of income a cottage food operation can earn and still qualify as a cottage food operation." 55 The Study found that most, but not all, limitations were based on dollar amounts, which ranged from $\$ 5,000$ to $\$ 50,000$ per year. ${ }^{56}$ Fifth, the Study found that "almost all states with cottage food laws have labeling requirements," most of which mandated common disclosures. $^{57}$

These long-standing cottage food laws form the basis of exemptions from the general state and local food law requirements that, in turn, are largely based on an FDA-prescribed code. However, as illustrated by the Study's research on provisions discussed above, there remains considerable variation in what state cottage food laws permit to fall outside of the food regulation ambit.

${ }^{48} I d$.

${ }^{49} I d$. at 10.

${ }^{50} I d$.

${ }^{51} I d$.

${ }^{52} I d$.

${ }^{53}$ Id. (noting that restrictions limit sales to "farmers markets, county fairs, roadside stands, on the producer's premises, and through community supported agriculture operations").

${ }^{54} \mathrm{Id}$. at 13

${ }^{55}$ Id. at 14 .

${ }^{56} I d$.

${ }^{57}$ Id. at 16 ("Generally, cottage food products are required to be labeled with some combination of the following information: Name and address of producer; [c]ommon or usual name of product; [i]ngredients of product in descending order of predominance by weight; [a]ny food allergens; [n]et weight and volume of food product by standard measure or numerical count; [d]ate on which the food was processed; and [a] statement similar to the following: 'Made in a home kitchen that has not been inspected by the (state)'s department of health (or agriculture." ). 


\section{Food sovereignty}

Food sovereignty is part of an international movement to constitutionalize a right to food that is seeking to find a foothold in the American political landscape. ${ }^{58}$ The first global forum on food sovereignty was held in Mali in 2007 and resulted in the Declaration of Nyéléni, ${ }^{59}$ which provides, in part, this definition:

Food sovereignty is the right of peoples to healthy and culturally appropriate food produced through ecologically sound and sustainable methods, and their right to define their own food and agriculture systems. It puts the aspirations and needs of those who produce, distribute and consume food at the heart of food systems and policies rather than the demands of markets and corporations. ${ }^{60}$

Food sovereignty is most often associated with its international advocates, such as La Via Campesina, or the International Peasant's Movement ${ }^{61}$ as well as international policies, such as General Comment 12 to the International Covenant on Economic, Social and Cultural Rights, which defines the right to adequacy of food as realized when "every man, woman and child, alone or in community with others, has physical and economic access at all times to adequate food or means for its procurement."62 The United States is not a party to this covenant.

The food sovereignty movement in the United States, however, has struggled to find a true legal footing. For instance, the Supreme Court has never recognized a right to food, and the food sovereignty movement had little impact on the FSMA. ${ }^{63}$ However, the movement is gaining some traction at the state and local level.

No state has invested more in the food sovereignty movement than Maine. A 2011 joint resolution passed by the Maine Legislature provided that the "basis of human sustenance rests on the ability of all people to save seed and grow, process, consume and exchange food and farm products," and thus resolved, "to oppose any federal statute, law or regulation that attempts to threaten our basic human right to save seed and grow, process, consume and exchange food and farm products within the State of Maine." ${ }^{.64}$ Further, between 2011 and 2014, eleven Maine towns have passed

${ }^{58}$ See J.M. Greene, Localization: Implementing the Right to Food, 14 DRAKE J. AGRIC. L. 377, 390-94 (2009); Michael J. McDermott, Constitutionalizing an Enforceable Right to Food: A Tool for Combating Hunger, 35 B.C. INT'L \& COMP. L. REV. 543 (2012) (discussing movements to constitutionalize a "right to food"); cf. Samuel R. Wiseman, Liberty of Palate, 65 ME. L. REV. 737 (2013) (dismissing claims that the Constitution provides a fundamental right to food).

${ }^{59}$ See Nathan Bellinger \& Michael Fakhri, The Intersection Between Food Sovereignty and Law, 28 NAT. RESOURCES \& ENV'T 45, 45 (2013).

${ }^{60}$ Declaration of Nyéléni, Feb. 27, 2007, available at http://nyeleni.org/ spip.php?article290.

${ }^{61}$ LA VIA CAMPESINA, http://viacampesina.org/en/ (last visited Mar. 14, 2015).

${ }^{62}$ United Nations, Econ. \& Soc. Council, Comm. on Econ., Soc.. \& Cultural Rights, General Comment No. 12, The Right to Adequate Food, at 3, 6, U.N. Doc. E/C.12/1999/5 (May 12, 1999); see also Smita Narula, The Right to Food: Holding Global Actors Accountable Under International Law, 44 CoLuM. J. TRANSNAT'L L. 691, 735-36 (2006).

${ }^{63}$ Baylen J. Linnekin, The "California Effect" \& the Future of American Food: How California's Growing Crackdown on Food \& Agriculture Harms the State \& the Nation, 13 CHAP. L. REV. 357, 387-88 (2010).

${ }^{64}$ H.R.J. Res. 1176, 125th Leg., 1st Reg. Sess. (Me. 2011); see also Aaron Libby, Maine Passes Joint Resolution on State Food Sovereignty, FOOD FREEDOM (June 13, 2011), $\mathrm{http}$ //foodfreedom.wordpress.com/2011/06/13/maine-passes-joint-resolution-on-state-food-sovereignty/. 
versions of the Local Food and Self Governance Ordinance of 2011 (the "Local Food Ordinance"), a model ordinance based upon food sovereignty principles. ${ }^{65}$ The preamble of the Ordinance provides, "We hold that federal and state regulations impede local food production and constitute a usurpation of our citizens' right to foods of their choice." provisions, which include exemptions from licensure and inspection, as well as affirmative rights such as "the right to produce, process, sell, purchase, and consume local foods." ${ }^{7}$ In effect, the Local Food Ordinance establishes a rights-based approach to food that suggests a mere statute or ordinance could not supersede.

The legality of these rights-based ordinances, however, was tested in a recent case, State v. Brown, where a dairy farmer in the town of Blue Hill, which had passed a version of the Local Food Ordinance, sold raw milk directly to customers but refused to obtain state licenses. ${ }^{68}$ Among the questions before the court was whether the Blue Hill ordinance could remove the obligation of the farmer to obtain the state license. In reviewing the Blue Hill ordinance, however, the Maine Supreme Court used canons of construction to avoid conflict with state law, and thus held that, since the Blue Hill ordinance did not expressly state that it sought to preempt state or federal law, "[w]e construe the plain language of the Blue Hill Local Food Ordinance to exempt local food producers and processors only from municipal licensing and inspection requirements. . . So limited, the issue of preemption is avoided." ${ }^{69}$

While the Maine Supreme Court's ruling in State v. Brown can be commended for its judicial restraint in conformance with established rules of statutory construction, doing so also permitted the court to avoid the fight the food sovereignty movement wanted. The food sovereignty movement is clearly structured to pit established principles of federalism and supremacy against local government's home rule powers. By not reaching those questions, the State v. Brown court also left open the question of local government's ability to assert rights to food freedom from state or federal regulations to food production. In addition to the Local Food Ordinance, there are other model ordinances, such as the Food Bill of Rights model ordinance, which pick similar fights. ${ }^{70}$ Similar food sovereignty ordinances have also been passed around the country at the local level. ${ }^{71}$ Even if ultimately futile in light of federalism's

\footnotetext{
${ }^{65}$ Hilda E. Kurtz, Framing Multiple Food Sovereignties: Comparing the Nyeleni Declaration and the Local Food and Self-Governance Ordinance in Maine, in FOOD SOVEREIGNTY IN INTERNATIONAL CONTEXT (Amy Trauger ed., 2015).

${ }^{66}$ Maine, Local Food and Community Self-Governance Ordinance (Mar. 21, 2011), available at http://www.farmlandinfo.org/sites/default/files/Maine_Food_and_Community_Model_Law_1.pdf

${ }^{67} \mathrm{Id}$.

${ }^{68}$ State v. Brown, 95 A.3d 82, 84 (Me. 2014). The raw milk debate has garnered national attention. See Megan Loder, A Raw Deal: Why Texas Should Relax and Let Dairies Bring Their Milk into Town, 15 TEX. TeCH. AdMIN. L.J. 231, 251 (2013); Ryan Almy, Note, State v. Brown: A Test for Local Food Ordinances, 65 ME. L. REV. 789, 791 (2013); Jess Bidgood, Maine Court Fight Pits Farmers Against State and One Another, N.Y. TIMES (June 18, 2014), http://www.nytimes.com/2014/ 06/19/us/maine-court-fight-pitsfarmers-against-state-and-one-another.html? $\mathrm{r}=0$.

${ }^{69}$ Brown, 95 A.3d at 91.

${ }^{70}$ See Model Food Bill of Rights, CMTY. ENVTL. LEGAL DEF. Fund, http://celdf.org/-1-77 (last visited Mar. 14, 2015)

${ }^{71}$ See Alexis Baden-Mayer \& Katherine Paul, Can Food Sovereignty Laws Protect Local Farms from Annihilation?, ORGANIC CONSUMERS ASS'N. (Sept. 11, 2013), https://www.organicconsumers.org /news/can-food-sovereignty-laws-protect-local-farms-annihilation.
} 
unwavering principles of supremacy and preemption, the food sovereignty movement's toe-hold at the local level indicates a desire for hyper-local control over food agritourism and, further, an increasing concern with even local regulation on agriculture and food production that might interfere with the relationship between farmers and those they feed.

\section{Food Freedom}

Food freedom is the least well defined, and perhaps also the least powerful, of the three local food producer anti-regulation movements. Nonetheless, its rise is indicative of a desire to have less state and local government involvement in local food production. $^{72}$ Thus far, no explicit "food freedom" legislation has been passed; however, its prevalence in statehouses around the country as proposed legislation is indicative of a rising tide that could potentially result in more legislation that could, in fact, become law.

Arguably the most dramatic food freedom bills were those proposed in 2012 sessions of the Utah and New Hampshire legislatures, which purported to exempt local food from federal regulation, a clear effort to challenge the legitimacy of the FSMA. The Utah bill proposed that an agricultural product grown or produced in the state that remained in Utah would not be subject to regulation by the federal government, and, moreover, any officer, employee, or agent of Utah or an officer, employee, or agent of any of Utah's political subdivisions who enforced federal food safety law would be guilty of a misdemeanor. ${ }^{73}$ A review by the state's legislative counsel noted that "there is a high probability that a court will find that this bill violates the Supremacy Clause" and the legislation was not passed. ${ }^{74}$ The proposed New Hampshire Food Freedom Act provided that "all foodstuffs that are grown in and remain within the borders of the state of New Hampshire shall be regulated solely by the state of New Hampshire and shall not be subject to federal regulation, nor inspection of growing or production facilities by federal official or their agents." ${ }^{.75}$ The bill also prevented municipalities from making or enforcing "any food ordinance or bylaw which is more restrictive than the requirements" of the state food laws. ${ }^{76}$ The New Hampshire bill was also rejected.

Not all "food freedom" bills have had such explicit anti-federal government regulation; however, most seek to limit state and local government regulations on local food. In Wyoming, the state legislature in 2013 tried to pass the "Wyoming Food Freedom Act." ${ }^{, 77}$ Although the bill passed the House, it died in the Senate. ${ }^{78}$ Among the bill's provisions were ones that would have prohibited "licensure, permitting, certification, inspection, packaging or labeling required by any state governmental agency or any agency of any political subdivision of the state which pertains to the

\footnotetext{
${ }^{72}$ See Precedent Setting Agriculture Bill Signed by Governor Terry McAuliffe, FARM-TO-CONSUMER LEGAL DEF. FUND (March 10, 2014), http://www.farmtoconsumer.org/news_wp/?p=14803.

${ }^{73}$ S. 34, 2012 Leg., Gen. Sess. (Utah 2012).

${ }^{74}$ Legislative Review Note, S. 34, 2012 Leg., Gen. Sess. (Utah 2012).

${ }^{75}$ H.R. 1650-FN, 2012 Leg., Reg. Sess. (N.H. 2012).

${ }^{76} \mathrm{Id}$.

${ }_{78}^{77}$ H.R. 108, 62nd Leg., Gen. Sess. (Wyo. 2013).

${ }^{78} I d$.
} 
preparation, serving, use, consumption, or storage of' local food products. ${ }^{79}$ Similar bills in other states, such as Idaho, ${ }^{80}$ Georgia, $^{81}$ and Mississippi ${ }^{82}$ have also proposed no licensing of local food, but none have been passed. Similarly, a proposed bill in Virginia would have eliminated inspections and examinations of home kitchens. ${ }^{83}$

Food freedom has even reached Congress, where two Representatives, Kentucky Representative Thomas Massie and Maine Representative Chellie Pingree, proposed two bills - the "Milk Freedom of Act of 2014" and the "Interstate Milk Freedom Act of 2014" -that seek to eliminate the FDA's regulations banning the interstate sale of unpasteurized milk. ${ }^{84}$ According to one of the representatives, this is "the first in a series of 'food freedom' bills that Rep. Massie plans to introduce this year," no subsequent "food freedom" legislation is evident.

\section{IMPLICATIONS OF FOOD DEREGULATION FOR THE FOOD AGRITOURISM INDUSTRY}

Collectively, small farmer and food producer exemptions in the federal FSMA, and the cottage food, food sovereignty, and food freedom movements seeking exemptions from food regulation at the state or local level, indicate an overall frustration with food regulation by small farmers and producers. Indeed, it may well be that food agritourism still faces too much food safety regulation. The emergent food agritourism industry, however, will have to decide whether pursuing deregulation from federal, state, and local governments ultimately makes sense as a strategy for economic growth. Food agritourism is presently a small, largely upper-middle class industry. ${ }^{86}$ While it appeals to some because of its lack of corporate-ism, for most it is an experience with a sense of small-scale luxury. ${ }^{87}$ Food agritourism will not become more mainstream if there is a growing sense that participation in food agritourism activities presents a higher risk of food safety. The veneer of health that food agritourism presently enjoys could very quickly be ruined by just a few bad actors. Rather than no regulation, a more coherent and rational regulation of food agritourism makes better sense.

${ }^{79} \mathrm{Id}$.

${ }^{80}$ H.R. 431, 61st Leg., 2nd Reg. Sess. (Idaho 2012).

${ }^{81}$ H.R. 12, 151st Gen. Assemb., Reg. Sess. (Ga. 2011).

${ }^{82}$ S. 2516, 2013 Leg., Reg. Sess. (Miss. 2013).

${ }^{83}$ H.R. 135, 2013 Gen. Assemb., Reg. Sess. (Va. 2014); see also Kenric Ward, Farmers Win Land-Use Fight; 'Food Freedom' Next, WATCHDOG.ORG (Mar. 3, 2014), http://watchdog.org/130709/farmers-landfood $/$

${ }^{84}$ Milk Freedom Act of 2014, H.R. 4307, 113th Cong. (2014); Interstate Milk Freedom Act of 2014, H.R. 4308, 113th Cong. (2014).

${ }^{85}$ Press Release, U.S. Rep. Thomas Massie, U.S. Representative Massie Introduces Bipartisan Milk Freedom Legislation (Mar. 27, 2014), available at http:/massie.house.gov/press-release/press-release-usrepresentative-massie-introduces-bipartisan-milk-freedom-legislation.

${ }^{86}$ See Dawn Thilmany et al., The 2006 Economic Contribution of Agritourism to Colorado: Estimates from a Survey of Colorado Tourists, 24 DEP'T OF AGRIC. \& REsOURCE ECON. ECON. DEV. REP. 1, 4 (2007), https://www.colorado.gov/

pacific/sites/default/files/The $\% 202006 \% 20$ Economic\%20Contribution $\% 20$ of $\% 20$ Agritourism $\% 20$ to $\% 20 \mathrm{Col}$ orado 1 .pdf.

${ }_{\overline{87}}$ See Cynthia Ord, Can Agritourism Save Small-Scale Farming?, TRAVEL Word (Sept. 4, 2012), $\mathrm{http}: / / \mathrm{www}$.thetravelword.com/2012/09/04/can-agritourism-save-small-scale-farming. 


\section{THE CASE OF LOCAL BUILDING AND ZONING LAWS}

Food safety regulations, while potentially onerous, are really just the tip of the iceberg in terms of regulatory problems faced by local food producers in rural areas. Many such producers are engaged in a number of on-farm diversification activities, which often mix food and other types of entertainment. Trying to engage in such activities, however, can quickly lead to regulatory problems, most often with county building and planning departments.

Many food agritourism activities first encounter these issues in trying to convert farm buildings to spaces of public accommodations. For instance, a farmer may try to offer dairy barn tours to local schools, or to convert a working barn to a space for weddings or farm-to-table dinners. ${ }^{88}$ From a building code perspective, however, that is a substantial change in use: agricultural buildings are typically not regulated by standard building codes, while public accommodation spaces are typically among the most regulated building structures because of the potential for mass injury. ${ }^{89}$ Upgrading a barn to meet public safety standards can be cost-prohibitive, and finding a regulatory middle ground is not always easy.

These regulatory struggles have left many food agritourism providers to seek exemptions from local building and zoning codes under state exemptions for "agriculture." However, several recent state court decisions have narrowly construed the definition of agriculture, and thus shut the door, in many states, on food agritourism seeking exemptions intended for agriculture. That has not sat well with farmers; as recently passed legislation in Virginia illustrates, farmers are fighting back and obtaining state legislation specifically prohibiting local governments from regulating food agritourism uses under local building or zoning codes. This section first reviews recent court cases holding that food agritourism uses do not qualify for agricultural exemptions from local building and zoning codes, then considers the Virginia statutory response mandating such an exemption.

\section{A. THE EXClusion of FoOd Agritourism from Agricultural EXEMPTIONS TO BUILDING AND ZONING CODES}

Within the last two years, at least four cases have considered whether local food agritourism operations could secure protection from local regulation by fitting within exemptions for "agriculture." In sum, courts have been unwilling to expand definitions of agriculture to include food agritourism, thus opening these uses to the full extent of building and zoning code regulation.

Take, for instance, a 2013 Tennessee case, Shore v. Maple Lane Farms, LLC, ${ }^{90}$ which illustrates how such agritourism uses are complicating definitions of agriculture. Maple Lane Farms addresses the slow-growth of agritourism uses on a farm in an exurb of Knoxville, Tennessee. Maple Lane Farms began in the mid-1980's as a

\footnotetext{
${ }^{88}$ See Julie Bosman, Neighbors Say Barn Weddings Raise a Rumpus, N.Y. TIMES (Aug. 3, 2014), http://www.nytimes.com/2014/08/04/us/neighbors-say-barn-weddings-raise-a-rumpus.html?_r=0; Symmes \& Edwards, supra note 4.

${ }^{89}$ See Alameda Cnty. Pub. Works AgEncy, Butlding Code Analysis for COnVERTing EXISTING AGRiclltural BUILDINGS TO WINE TASTING/Event CEnTERS, www.acgov.org/pwa/ documents/Agricultural-Building-Conversion.pdf.

${ }^{90}$ Shore v. Maple Lane Farms, LLC, 411 S.W.3d 405 (Tenn. 2013).
} 
family operation of raising cattle and growing various vegetables, including pumpkins. $^{91}$ Eventually, Maple Lane Farms began to diversify their operation by offering various activities for visitors. These included strawberry picking festivals, inflatables, corn mazes, hay rides, pumpkin patches, and antiquing. ${ }^{92}$ At some point, Maple Lane Farms also began hosting music concerts during these events. ${ }^{93}$ This diversification was lucrative for Maple Lane Farms, accounting for $75 \%$ of the farm's income from 2006 to $2008 .^{94}$ In 2003 , Mrs. Shore moved to a subdivision adjacent to Maple Lane Farms. ${ }^{95}$ Although Mrs. Shore enjoyed some of the events at Maple Lane Farms, she complained about the noise, traffic congestion, and left-over trash that occurred during and after the music concerts. ${ }^{96}$ Mrs. Shore sought relief from various county boards and eventually, after a number of appeals by both parties, the county Zoning Board ruled that Maple Lane Farms could hold only one concert per year. $^{97}$ Maple Lane Farms disregarded the decision, reasoning that their farm was an agricultural activity that was exempt from regulation and was protected by the Tennessee Right to Farm statute. ${ }^{98}$

Ms. Shore filed suit against Maple Lane Farms seeking a declaration that the music concerts were not protected by the Right to Farm Act, were therefore subject to zoning regulations, and further, constituted a nuisance. ${ }^{99}$ Both the trial court and Court of Appeals dismissed Ms. Shore's lawsuit, finding that the activities were agricultural in nature. ${ }^{100}$ The trial court found that Maple Lane Farms was an active farming operation under the Tennessee Right to Farm Act and that Ms. Shore did not rebut the presumption in the Right to Farm Act that farming operations were not a nuisance. ${ }^{101}$ In affirming this decision, the Court of Appeals found that the activities at Maple Lane Farms were agritourism, which is the equivalent of agriculture under the Tennessee Right to Farm Act. ${ }^{102}$ Ms. Shore appealed the decision of the Court of Appeals.

In a unanimous opinion, the Tennessee Supreme Court reversed the lower courts' dismissal of the lawsuit, finding that the lower courts "overlooked" the threshold issue of whether the activities complained of were covered by the Right to Farm Act. ${ }^{103}$ The court explained that the "Tennessee Right to Farm Act does not extend nuisance protection to all activities occurring on a farm." 104 Instead, the protection is applicable "only to the "land, buildings and machines used in the commercial production of farm products ....." The mere fact that some farming activity occurs at Maple Lane

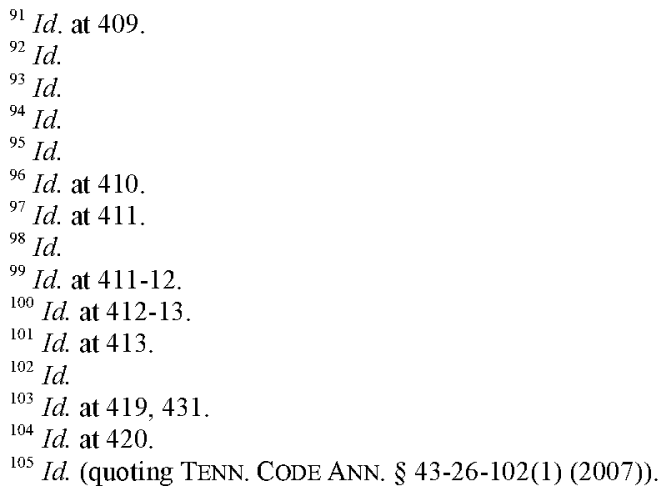


Farms was insufficient; the question instead was whether the music concerts that Ms. Shore complained of were part of a farm operation as covered by the Act. ${ }^{106}$ The Supreme Court found that the concerts did not fall under this definition because the music concerts "bore no relation to the production of cattle, corn, vegetables, strawberries, or pumpkins at Maple Lane Farms." ${ }^{107}$ The court also found that the music concerts did not meet the definition of "agriculture" to be exempt from county zoning regulation. ${ }^{108}$

As the Tennessee Supreme Court noted, agriculture is changing, and it is likely that these issues will continue to arise across the country. ${ }^{109}$ Producers and landowners are diversifying and adding different types of activities to their farms in order to generate income. Other examples of this type of diversification include hunting leases, roadside vegetable and fruit stands, and pumpkin patches. Whether these activities will fall within the protection of a state right-to-farm act will depend on the specific language of the act and the specific facts of each case.

In addition, another 2013 case, Greenfield v. Multnomah County, ${ }^{110}$ illustrates how litigation can arise from ambiguity in a state statute defining agriculture. Greenfield v. Multnomah County arose out of dispute concerning the extent of a modification to a farm stand permit granted to Bella Organic (Bella). Bella requested a modification to its farm stand permit that would allow it to conduct a variety of fee based activities, including small gatherings, birthday parties, harvest festivals and farm-to-plate dinners for 150 people, totaling forty-five events per year. ${ }^{111}$

The application was heard by a hearings officer who approved (1) farm-to-plate dinners, but reduced the amount of guests to seventy-five, and the number of events to twenty per year, (2) up to twenty-four harvest festivals, including use of a food cart for fee based activities; and (3) "small scale gatherings such as birthdays, picnics, and similar activities."112 Bella also requested to use tents on the property in connection with the dinner events and other activities, which the hearings officer denied ${ }^{113}$ Both Bella and the opposing party, Greenwood, appealed the decision to the Land Use Board of Appeals (LUBA).

After review, LUBA concluded that farm-to-plate dinners were "banquets" which were prohibited under the farm stand statute. ${ }^{114}$ Additionally, LUBA agreed with the hearings officer that tents and viewing structures were improper because they were only used in connection with promotional activities, not agricultural activities. ${ }^{115}$ Finally, LUBA concluded that the small-scale gatherings were permissible. ${ }^{116}$ All three parties-the County, Bella and Greenfield-appealed.

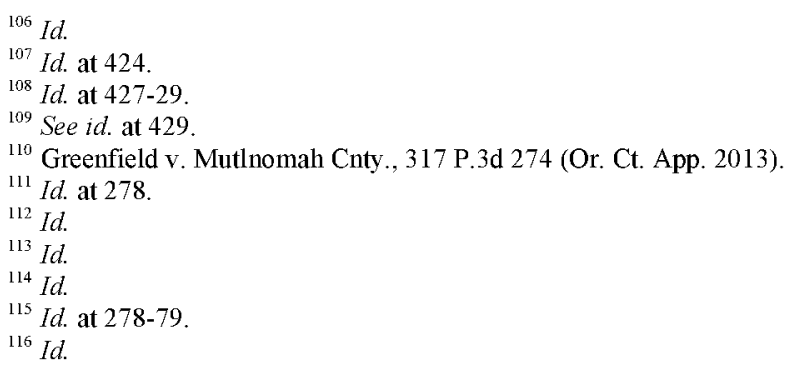


The issues on appeal concerned the interpretation of Oregon's farm stand statute, which authorizes farm stands as a permitted use in the exclusive farm zone. ${ }^{117}$ The statute also authorizes the sale of incidental retail items and fee-based promotional activities. ${ }^{118}$ The court turned to the legislative history of the bill, and concluded that the farm stand statute "pertained exclusively to the use and design of the farm stand structure" and also allowed the sale of farm products as incidental retail items. ${ }^{119}$

Based upon its reading of the farm stand statute, the court disagreed with LUBA when it concluded that outdoor promotional dinners are not an allowed promotional activity because "banquets" are not permitted in a farm stand structure. ${ }^{120}$ The court remanded the issue to consider additional procedural issues related to the County's allowance of farm-to-plate dinners. ${ }^{121}$ Next, the court agreed with LUBA that any structure on a farm stand must be used predominantly for the sale of farm crops or livestock. ${ }^{122}$ Further, the court looked to the definition of "structures" and concluded that food carts were structures for purposes of the farm stand statute and thus they are only permissible if they are "designed and used for the sale of farm crops or livestock grown on the farm operation and are not designed for activities other than the sale of farm crops or livestock." 123 Finally, the court agreed with LUBA and determined that small-scale gatherings could be allowed if there were designed to promote the sale of products at the farm stand. ${ }^{124}$

The court remanded the case to LUBA, and possibly the County on further remand, to determine whether food carts meet the requirements for farm stand structures, and to determine the additional procedural issues of the County allowing farm to plate dinners. ${ }^{125}$

A similar unwillingness to grant agritourism activities the exemptions for agriculture is exhibited by a recent Oregon tax case addressing agritourism. In Lakeview Farms v. Washington County Assessor, the tax assessor asserted that the property at issue was used for commercial purposes, rather than farming. ${ }^{126}$ The plaintiff contended that his pumpkin patch operation was an agricultural activity constituting "agri-tourism" and presented evidence that the State of Oregon acknowledges and supports "agri-tourism." "127 The court recognized "agritourism" as "a commercial enterprise at a working farm . . . conducted for the enjoyment of visitors that generates supplemental income for the owner," ${ }^{28}$ but determined that in

${ }^{117} \mathrm{Id}$.

${ }^{118} I d$.

${ }^{119} I$ Id. at 282 .

${ }^{120} \mathrm{Id}$. at 284 .

${ }^{121} I d$.

${ }^{122}$ Id. at $284-85$.

${ }^{123}$ Id. at 287 (internal quotation marks omitted).

${ }^{124} \mathrm{Id}$. at 289

${ }^{125} I d$. at 290 .

${ }^{126}$ Lakeview Farms v. Wash. Cnty. Assessor, No. TC-MD 100443D, 2011 WL 4852468, at *3 (Or. Tax Ct. Oct. 13, 2011); see also Shore v. Maple Lane Farms, LLC, No. E2011-00158-COA-R3-CV, 2012 WL 1245606, at *12 (Tenn. Ct. App. Apr. 11, 2012), rev'd, 411 S.W.3d 405 (Tenn. 2013) (discussing same and providing summary)

${ }^{127} I d$. at $* 10$.

${ }^{128}$ Id. at $* 2$ (quoting BritTANY RusSEll, Agri-BuS. COUNCLL OF OR., AGRI-TOURISM WORKBOOK:

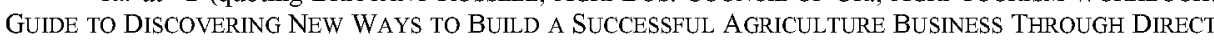
FARM MARKETING 12 (2003)) (internal quotation marks omitted). 
the absence of legislative amendments, the Oregon Supreme Court had "declined to allow an exemption for activities not traditionally included in the definitions of 'farm' or "agriculture' or explicitly stated in the applicable statute." 129 The Lakeview Farms court recognized that the courts of Oregon "ha[d] declined to extend the concept of 'agriculture' beyond that traditional definition in the absence of clear legislative intent." 130

Similarly, a U.S. bankruptcy court rejected an application of an agritourism operator that used a rural property for recreational activities open to the public for a fee, including ice skating, skate sharpening, sledding, hayrides and archery, in addition to growing pumpkins and watermelons on land other than the subject property, to file for bankruptcy under provisions for farmers. ${ }^{131}$ The bankruptcy court concluded that the operator's "assertion that agritourism is a farming operation is not supported by the letter or spirit" of the Bankruptcy Code. ${ }^{132}$ The court added, "By his logic Disneyland is a farming operation because it was built on land that had formerly been an orange grove." 133

These four cases are indicative of the increasing litigation faced by the uncertain position of food agritourism: because of food agritourism's unique blend of activities and uses, courts have been unwilling to grant access to broad exemptions for agricultural uses; on the other hand, the full applicability of building and zoning codes, intended to regulate urban uses, to these food agritourism projects is onerous.

\section{B. STATUTORY EXEMPTIONS OF FOOD AGRITOURISM FROM BUILDING AND ZONING CODES}

In response to the frustration over permitting, and in light of cases that have not provided relief under agricultural exemptions, legislation is now taking shape at the state level to limit local land use controls over agritourism uses. Notable here is legislation enacted in 2014 in Virginia. ${ }^{134}$ In Virginia, the Governor recently signed a landmark agriculture bill, creating more rights and economic opportunities for small family farms. ${ }^{135}$ Senate Bill 51 amends the Code of Virginia to add a section 15.22288.6 , relating to local regulation of activities, which provides that local governments must not prevent "the carrying out of any of the following activities at an agricultural operation ... unless there is a substantial impact on the health, safety, or general welfare of the public," which includes agritourism activities; the preparation, processing, or sale of food products; or "other activities or events that are usual and customary at Virginia agricultural operations." 136 Further, the legislation provides that no local government "shall require a special exception, administrative permit not required by state law, or special use permit for any [agritourism] activity on property that is zoned as an agricultural district or classification unless there is a substantial

\footnotetext{
${ }^{129} I d$ at $* 6$

${ }^{130} \mathrm{Id}$. at $* 10$.

${ }^{131}$ See In re Vecchione, No. 13-42201-MSH, 2013 WL 6164332 (Bankr. D. Mass. 2013)

${ }^{132} I d$. at $* 2$.

${ }^{133} I d$.

134 See Ward, supra note 83.

${ }^{135}$ See FARM-TO-CONSUMER LEGAL DEF. FUND, supra note 72.

${ }^{136}$ VA. CODE ANN. § 15.2-2288.6.A. (2012 \& Supp. 2014).
} 
impact on the health, safety, or general welfare of the public."137 It is too soon to know whether the Virginia legislation will gain momentum in other states, much less whether it will have any significant impact within Virginia. It could be that local governments in the state will be able to easily meet the health and safety requirements that would allow for regulation of agritourism uses. Nonetheless, the legislation's mere presence is likely to have a chilling effect on Virginia's local governments' willingness to regulate in the gray areas that food agritourism occupies.

\section{IMPliCATIONS OF BUILding AND ZONING DEREgulation FOR THE FoOD AGRITOURISM INDUSTRY}

Thus far, the Virginia statute making it more difficult for local governments to apply building and zoning codes to food agritourism uses appears to be an outlier; the majority of states continue to provide rural building and zoning exemptions explicitly to agricultural uses, and most still view such exemptions narrowly to exclude food agritourism. $^{138}$ Here again, food agritourism faces a difficult choice: building and zoning codes are built around urban use, and focus on protections needed for urban living. At the same time, deregulation from building and zoning codes can lead to shoddy construction practices more likely to result in injury. Again, food agritourism is an industry where people are not expecting to be hurt or face increased danger beyond what they might find in their grocery aisle. An industry perceived as skirting all regulation becomes more questionable in the minds of potential customers. Like with food safety, a more coherent regulatory structure for food agritourism buildings and uses makes more sense than outright deregulation.

\section{ALTERNATIVES TO DEREGULATING THE LOCAL FOOD LANDSCAPE}

The problems associated with over-regulation of food agritourism are readily enough perceived: too much regulation will destroy the nascent industry. On the other hand, deregulation of food agritourism also has problems that its proponents may not find so obvious. First, deregulation is problematic for the industry when, inevitably, accidents and illness result from operations. A major 2011 study by the Centers for Disease Control estimated that, at the time, "each year roughly 1 in 6 Americans (or 48 million people) get sick, 128,000 are hospitalized, and 3,000 die of foodborne

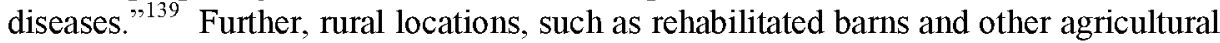
equipment, have inherent risks associated with them because most were not built for human use. Whether it is a foodborne illness or an injury resulting from a building defect, complete deregulation could easily cause a backlash against food agritourism.

\footnotetext{
${ }^{137} I d . \S 15.2-2288.6 . \mathrm{B}$.

138 See RoBert ANDREW BRANAN, NAT'L AGRIC. LAW CTR., ZONING LiMITATIONS AND OPPORTUNITIES FOR FARM ENTERPRISE DIVERSIFICATION: SEARCHING FOR NEW MEANING IN OLD DEFINITIONS 3 (2004), http://nationalaglawcenter.org/publication/branan-zoning-limitations-andopportunities-for-farm-enterprise-diversification-searching-for-new-meaning-in-old-definitions-nationalaglaw-center-publications-2004/wppa_open.

${ }_{139}$ CDC Estimates of Foodborne Illness in the United States, CDC, http://www.cdc.gov/foodborneburden/estimates-overview.html. According to the CDC, "these estimates are the first comprehensive estimates since 1999 and are the first ever to estimate illnesses cause [sic] solely by foods eaten in the United States." Id.
} 
Second, total deregulation eliminates licensing, the easiest mechanism for shutting down a "bad actor," altogether. This is especially problematic because just a few bad actors could ultimately taint and threaten the industry. Third, even minimal licensing provides a mechanism for information gathering, which can facilitate better coordination of the industry. Fourth, even a basic licensing structure provides a mechanism to ensure a minimum standard of industry best practices, whether related to food handling, hosting an event in a barn, or other food agritourism uses These are just some of the reasons why pursuing complete deregulation of food agritourism is a shortsighted remedy to overregulation.

As an alternative to both onerous regulation and deregulation, this section seeks to offer an alternative path that provides a minimum regulatory structure that would meet the following goals: provide a regulatory structure that protects public health and safety; maintain a reasonable regulatory burden relative to food agritourism's profit size; provide an alternative economic development strategy for local farmers; provide urbanites access to local food; and provide urbanites access to rural activities that may or may not be associated with food. ${ }^{140}$ The proposal here is necessarily conceptual given that a specific plan would need to be tailored to the unique circumstances where the food agritourism is taking place.

\section{A. FOOD AGRITOURISM DEVELOPMENT DISTRICTS}

Many food agritourism uses are clustered in rural location at the urban edge. ${ }^{141}$ Because of this proximity, it makes sense for these uses to be brought together to improve the visitor infrastructure for their food agritourism businesses. This could include things like signage, restroom facilities, marketing materials or a way-finding smartphone app. Urban businesses have, for nearly two decades, engaged in this kind of collective organization through business improvement districts, or BIDs. BIDs are enabled by state statute and, essentially, permit businesses within a given area to assess themselves a fee that is then collected and used for purposes approved of by the BID. ${ }^{142}$ To begin operation, BIDs typically require a vote of those property owners that would be assessed the fee. ${ }^{143}$

A similar approach could work in areas that wanted to advance food agritourism. Indeed, a model of sorts already exists. Texas already permits an "agricultural development district," "144 which merges traditional concepts of an agricultural conservation district with an agricultural economic development component. To encourage economic development, the district may: "foster[ ] the growth of enterprises based on certain types of agriculture;", 145 "stimulate[ ] innovation in certain agricultural

\footnotetext{
${ }^{140}$ For alternative approaches to the same issues, see Mary Jane Angelo et al., Small, Slow, and Local: Essays on Building a More Sustainable and Local Food System, 12 VT. J. ENVTL. L. 353 (2011) (collection of essays evaluating various aspects of "slow" and "local" food regulation).

${ }^{141}$ See Urban Edge AgParks, SustaINABLE AGRIC. EduC., http://www.sagecenter.org/projects/urbanedge-agparks/ (last visited Mar. 15, 2015).

${ }^{142}$ Richard Briffault, A Government for Our Time? Business Improvement Districts and Urban Governance, 99 COLUM. L. REV. 365, 367 (1999).

${ }^{143} I d$. at 378 .

${ }^{144}$ TEX. SPEC. DisTs. CODE ANN. $\$ \$ 3001.001$ - 3001.122 (2013 \& Supp. 2014).

${ }^{145} \mathrm{Id}$ \$ $3001.107(\mathrm{~b})(1)$.
} 
enterprises;" ${ }^{146}$ and "seek[ ] to eliminate unemployment or underemployment in the state." 147 The agricultural development section states that a district may "promote all agricultural enterprises, facilities and services of the district," as well as "encourage the maintenance and conservation of soil." ${ }^{.148}$ The district may not impose an ad valorem tax, but they may assess special fees upon members in the district. ${ }^{149}$

A similar structure could also be used for food agritourism: a state statute could enable those areas that wish to engage in, and grow, food agritourism to vote to assess themselves a fee that would go into a food agritourism development district that could, in turn, be used by a group to provide the kinds of upgrades and infrastructure to a rural area that would make them even more amenable to urban dwellers interested in food agritourism.

\section{B. STATEWIDE PlanNING AND MARKETING FOR FoOd AGRITOURISM}

In addition to permitting and facilitating food agritourism's self-funding through food agritourism development districts, the state and local governments could also encourage and engage in statewide planning for food agritourism. The more this is engaged in as part of a long-term, ground-up visioning exercise in which food agritourism providers have input, the more likely there is to be agreement between those providers and the regulators.

Second, the state can assist the development of food agritourism by revising relevant code provisions to either explicitly include or exclude food agritourism uses. One of the causes of overregulation, as well as litigation, is an uncertainty of which laws apply to a food agritourism use. As this article has discussed, litigation has arisen over whether food agritourism constitutes "agriculture," and there remains uncertainty over the applicability of exemptions in the FSMA to such food agritourism uses. Indeed, states that wish to encourage food agritourism may also want to revise their cottage food and other food agritourism-related laws to more explicitly reference food agritourism uses that are prominent—or which the state seeks to make prominent—in that state.

Third, a number of states are now offering some type of tax credits or liability waivers for those engaging in food agritourism uses. ${ }^{150}$ Finally, states with land grant universities may wish to create divisions specific to food agritourism within their farm extension programs to encourage its growth. ${ }^{151}$

\section{Coordinated Licensing and Permitting Strategies}

The price of the above state and local government's economic development assistance is appropriate and reasonable regulation of food agritourism uses. The complexity of regulating food agritourism arises because it is difficult to categorize;

${ }^{146} I d . \S 3001.107(\mathrm{~b})(2)$.

${ }^{147}$ Id. $\S 3001.107(\mathrm{~b})(3)$.

${ }^{148}$ Id. $\S 3001.108(1),(2)$

${ }^{149} I d$ Id. $\$ 3001.104$.

${ }^{150}$ See Stephen R. Miller, Agritourism at the Rural-Urban Interface: A National Overview of Legal Issues with 20 Proposals for Idaho 42-43, 52, 63 (May 9, 2014) (unpublished manuscript), available at http $/ /$ ssrn.com/abstract=2435306 (discussing multiple agritourism tax credit schemes across the country).

${ }^{151}$ See, e.g., Agritourism, UNIV. CAL., http://sfp.ucdavis.edu/agritourism/ (last updated Nov. 4, 2014). 
however, it is not the first use to exist where multiple regulatory jurisdictions overlap. It is from these other locations of regulatory complexity that food agritourism licensing and permitting should borrow.

The first goal of regulating food agritourism should be a coordinated licensing and permitting process. One approach would be to borrow ideas from places such as San Francisco Bay, where a project that would seek to fill the Bay requires permitting from, at a minimum, nine different agencies. ${ }^{152} \quad$ In response, the agencies created the Joint Aquatic Resource Permit Application (JARPA), which requires the applicant to place all information needed by all agencies in this one form. ${ }^{153}$ Similarly, food agritourism uses could be permitted through a common application that would address food safety, building codes, zoning codes, and anything else related to entitle a food agritourism use.

In coordinating multiple-agency regulation, another goal of a food agritourism use regulatory scheme should be creating one point of contact for all regulatory approval, which would give the food agritourism provider one person to speak to that is charged with coordinating all of the other permit applications.

An alternative regulatory scheme to ease permitting issues would be the development agreement approach to food agritourism pioneered by Weber County, Utah. In this agreement, the food agritourism provider contracts with the county for the type of use to be permitted, which gives both the county and the project applicant flexibility in recognition of site-specific considerations. ${ }^{154}$ The development agreement approach allows both the county and the food agritourism use to respond to specific considerations of both the regulatory and regulated parties that are likely to necessitate site-specific regulation. Further, a voluntary agreement relieves the county from due process and equal protection prohibitions on imposing site-specific regulation while also permitting the food agritourism user, in exchange for such regulatory flexibility, to also choose to provide public welfare or public safety components for a project that the county would not otherwise receive.

In both the coordinated permit and development agreement models, it would also be easier for federal government minimum requirements, such as those for food safety, to be incorporated into the permit or agreement, as is the case in many cooperative federalism regulatory models.

This model for regulating food agritourism is only a beginning. However, it illustrates that a coordinated effort to regulate and stimulate economic development in rural areas could provide much needed public safety regulations of the nascent food agritourism industry while also providing an incentive for the regulated community to work with state and local governments to grow rural incomes and provide equally needed financial opportunities to small farmers.

152 See S.F. Estuary P'ShIP, SAN Francisco BAY AREA JoINT AQUATIC Resource PERMIT APPLICATION, available at http://www.sfestuary.org/wp-content/uploads/2013/12/JARPA1 106-final.pdf.

${ }^{153} I d$.

${ }^{154}$ Weber County, Utah, Zoning Ordinance $\$$ 46-3.10. (2012). 


\section{CONCLUDING REMARKS}

Over the past decade, American urban dwellers have taken to tending their gardens like never before. Now, these urban Candides are taking to exploring the whole foodshed of the urban area, even its rural fringe. This provides an exceptional economic development opportunity for small farmers, who have increasingly needed income diversification to make small-scale farming economically feasible. Food agritourism uses offer an opportunity to assist small farmers in this income diversification in a way that also coalesces with the movement for local foods. The movement should be assisted by regulatory structures that provide for both economic development and public safety. Deregulation is not the route to take. Instead, there is a need to recognize food agritourism as a new form of use that requires its own coordinated regulatory structure. Just as food agritourism blends aspects of urban and rural cultures, aspects of urban and rural regulatory structures are also necessary. A coordinated regulatory and market response, as outlined in this article, could seize from today's regulatory morass a partnership to both grow the food movement and provide an economic stimulus to rural areas. 